\title{
Inside the Lifestyle of the Virophage
}

\author{
C. Desnues D. Raoult
}

Unité de recherche sur les maladies infectieuses et tropicales émergentes, URMITE CNRS-IRD UMR 6236, Faculté de Médecine, Marseille, France

\section{Key Words}

Amoeba viruses - Giant viruses - Mamavirus - Microscopy • Mimivirus $\cdot$ Satellite virus $\cdot$ Sputnik virophage $\cdot$ Viral factory $\cdot$ Viral RNAs

\begin{abstract}
Objective(s): We sought to better characterize Sputnik, the first isolated virophage, and to analyze its parasitic lifestyle during co-infection with Marseillevirus (a new giant virus) in Acanthamoeba castellanii. Methods: A combination of electron microscopy, immunofluorescence microscopy, and realtime PCR was used to characterize the kinetics of the viral replication cycle. RT-PCR was performed to detect RNAs inside the Sputnik virions. Results: Sputnik is a new viral entity carrying an almost complete ready-to-use set of viral RNAs (20 out of 21). Sputnik does not replicate with Marseillevirus but delays its replication cycle. While Marseillevirus is successfully internalized by $A$. castellanii following co-infections with Mamavirus and Sputnik, it does not initiate a replication cycle. In contrast, both Marseillevirus and Mamavirus can replicate in the amoeba in case of co-infection, but the development of one is exclusive from the other inside a single amoeba cell. Conclusions: This work provides new insight into the Sputnik replication cycle with another giant virus and confirms that Sputnik is a virophage. It shows new dimensions of the interactions existing among giant viruses.
\end{abstract}

Copyright $\odot 2010$ S. Karger AG, Basel
(C) 2010 S. Karger AG, Basel

$0300-5526 / 10 / 0535-0293 \$ 26.00 / 0$

Fax +4161306 1234

E-Mail karger@karger.ch

www.karger.com
Accessible online at: www.karger.com/int

\section{Introduction}

In 2003, a new giant virus named Acanthamoeba polyphaga Mimivirus (Mimivirus) was discovered in water collected from a cooling tower in Bradford, England [1]. By its size $(\sim 650 \mathrm{~nm}$ diameter) and its gene repertoire (>900 ORFs), Mimivirus outcompeted all other giant viruses described thus far [2]. For five years, Mimivirus was the only member of the Mimiviridae family, but in 2008, a new strain of Mimivirus was isolated from another cooling tower in Les Halles, Paris, France [3]. This virus was named Mamavirus. While the appearance (size and presence of fibrils) of Mamavirus largely resembled that of Mimivirus, its genome was slightly bigger [3]. However, the major distinctive feature of this new giant virus was its close association with a tiny 'companion' that we named Sputnik.

Sputnik is a small icosahedral virus (50 $\mathrm{nm}$ diameter). It harbors an 18-kb genome composed of 21 ORFs. More than a third of these ORFs do not have homologs in current databases, but some of them can be retrieved in environmental metagenomic datasets. Further, Sputnik's genome contains a mosaic of genes related to bacteriophages, archaea viruses and its Mamavirus host [3]. Mamavirus infection by Sputnik leads to the formation of some abnormal Mamavirus particles and a significant decrease in amoebal lysis. Sputnik is also able to infect Mimivirus, but the number of co-infected amoebae is lower [3]. Through its ability to generate defective Mamavirus virions and to attenuate Mamavirus infectivity for the amoeba, Sputnik is a legitimate parasite rather than a simple satellite. This unprecedented discovery led us to

Christelle Desnues

Unité de recherche sur les maladies infectieuses et tropicales émergentes URMITE CNRS-IRD UMR 6236, Faculté de Médecine, 27, Bd Jean Moulin FR-13385 Marseille (France)

E-Mail christelle.desnues@univmed.fr 
coin the generic term of virophage to describe a virus infecting another virus. Whether Sputnik should be classified as a virophage or a satellite has been a matter of debate ever since, and through this work (and others to come), we want to address this issue.

Here, we provide insight on new elements of the cell cycle of Mamavirus and its virophage. After a brief description of the Mamavirus and Sputnik replication cycle, we characterize the effect of Sputnik infection on another giant virus named Marseillevirus (described in [4]). We further present results concerning the co-infection of the amoebal host with Marseillevirus, Mamavirus and the Sputnik virophage. In addition, we demonstrate the presence of viral RNAs packaged inside the Sputnik virions. Finally, in light of these results, we explain the reasons why Sputnik can undoubtedly be called a virophage.

\section{Material and Methods}

\section{Virus Isolation}

Mamavirus and the Sputnik virophage were isolated as previously described [3]. Marseillevirus is a new giant virus isolated from biofilms formed in the waters of an industrial cooling tower. Details about Marseillevirus isolation are given elsewhere [4].

\section{Viral Infection}

Acanthamoeba castellanii cultures were seeded in peptoneyeast extract glucose medium at $10^{5}$ cells $/ \mathrm{ml}$ and infected with a mixture of Mamavirus and Sputnik, as previously described [3]. For co-infection, A. castellanii cultures were simultaneously infected with a mixture of Mamavirus, Sputnik and Marseillevirus, or Mamavirus and Marseillevirus. To survey the effect of Sputnik on the replication cycle of Marseillevirus, A. castellanii cells were first infected by Sputnik for $24 \mathrm{~h}$, and then Marseillevirus particles were added. At different times post-infection (p.i.), cultures were processed for electron and fluorescence microscopy.

\section{Electron Microscopy}

Infected $A$. castellanii cells were washed three times in PBS and fixed overnight with $2 \%$ glutaraldehyde in $0.1 \mathrm{M}$ cacodylate buffer. Cells were washed again with $0.1 \mathrm{M}$ cacodylate buffer, postfixed with $1 \%$ osmium tetroxide in $0.1 \mathrm{M}$ potassium ferricyanide for $1 \mathrm{~h}$, and dehydrated in increasing ethanol concentrations (from 30 to 100\%). Samples were embedded in Epon 812 resin. Sections $(70 \mathrm{~nm})$ were stained with $3.5 \%$ uranyl acetate and lead citrate before examination with a transmission electron microscope (Philips Morgagni 268D).

\section{Fluorescence Microscopy}

For immunofluorescence (IFF), $100 \mu \mathrm{l}$ of cell suspension was placed into a cytospin chamber, centrifuged at $800 \mathrm{rpm}$ for $10 \mathrm{~min}$ in a Shandon Cytospin 4 (Thermo Electron Corp.), and fixed for 10 min with a drop of methanol. DAPI (4',6'-diamidino-2phenylindole) was used to stain nucleic acids contained both in the cell nuclei and in the viral factories. Indirect IFF labeling was performed using rabbit anti-Mimivirus serum and mouse antiSputnik serum, as previously described [3].

\section{Viral Nucleic Acid Extraction, Real-Time and Reverse}

Transcriptase PCR

At different times p.i., DNAs were extracted from $200 \mu \mathrm{l}$ of culture following the fluid/blood protocol of the QIAamp DNA Mini Kit (Qiagen, Valencia, Calif., USA).

Real-time PCR was performed with a LightCycler FastStart DNA Master SYBR Green ITM kit in a standard PCR reaction, as described by the manufacturer (Roche Diagnostics, Mannheim Germany). Each reaction contained $3 \mathrm{mM} \mathrm{MgCl}_{2}, 1 \mu \mathrm{M}$ of each primer (primers for Mamavirus polymerase, Marseillevirus capsid, or Sputnik ORF20; table 1), and $5 \mu$ l of template DNA in a $20-\mu l$ PCR mixture. The amplification started with an initial denaturation step at $95^{\circ}$ for $10 \mathrm{~min}$, followed by 40 cycles of $95^{\circ}$ for $15 \mathrm{~s}, 57^{\circ}$ for $5 \mathrm{~s}$, and $72^{\circ}$ for $8 \mathrm{~s}$, with a temperature transition rate of $2^{\circ} \%$ s. Fluorescence signals were measured once in each cycle at the end of the extension step. After PCR amplification, $T_{m}$ curve analysis was performed. For each sample, the $\mathrm{C}_{\mathrm{T}}$ (Cycle Threshold) was given. The $\mathrm{C}_{\mathrm{T}}$ corresponds to the PCR cycle number at which the fluorescence reaches a threshold value of 10 times the standard deviation of the baseline emission. The $C_{T}$ values are inversely proportional to the starting amount of target DNA.

Detection of Viral RNA Packaged in the Sputnik Particle

Culture supernatants containing Sputnik particles were filtered through a $0.22-\mu \mathrm{m}$ membrane to remove contaminant cells and Mamavirus particles, and the filtrate was concentrated by ultracentrifugation ( $2 \mathrm{~h}$ at 22,000 rpm). To remove nucleic acids bound externally to the virions, $50 \mu \mathrm{l}$ of the concentrate was treated with RNAse (Roche) and DNAse I (Qiagen) for $1 \mathrm{~h}$ at $37^{\circ}$. Nucleases were inactivated at $70^{\circ}$ for $10 \mathrm{~min}$ in a mixture of $0.5 \mathrm{M}$ EDTA and $10 \%$ SDS, and then virions were digested with proteinase $\mathrm{K}(20 \mathrm{mg} / \mathrm{ml})$ for $1 \mathrm{~h}$ at $56^{\circ}$. RNAs were extracted using the RNAeasy Mini kit (Qiagen) and resuspended in $60 \mu \mathrm{l}$ of ultrapure water. Residual DNAs were removed via Turbo DNAse treatment (Ambion).

Reverse transcription of the mRNA was performed with MMLV reverse-transcriptase (Invitrogen) using random hexamers and following the manufacturer's recommendations. PCR of the cDNAs $(2 \mu \mathrm{l})$, using the HotStarTaq DNA Polymerase kit (Qiagen) and Sputnik specific primers (Sputnik ORF1 to Sputnik ORF21; table 1), were performed with one cycle of denaturation at $94^{\circ}$ for $15 \mathrm{~min}$, followed by 30 cycles of $30 \mathrm{~s}$ at $94^{\circ}, 30 \mathrm{~s}$ at $59^{\circ}, 45 \mathrm{~s}$ at $72^{\circ}$, and a final extension of $7 \mathrm{~min}$ at $72^{\circ}$. PCRs were also performed on mRNAs $(2 \mu \mathrm{l})$ to check for DNA contamination. RT-PCR products were analyzed by electrophoresis on $1.5 \%$ agarose gel and sequenced in both directions with an ABI Prism 3100 sequencer.

\section{Results}

\section{Morphological Characteristics of Mamavirus and Sputnik Particles}

Mamavirus shared numerous morphological features with its Mimivirus counterpart. For instance, Mamavirus particles appeared as purple dots under Gram staining (fig. 1a). Mamavirus has an icosahedral capsid, and 
Table 1. Primers used in this study

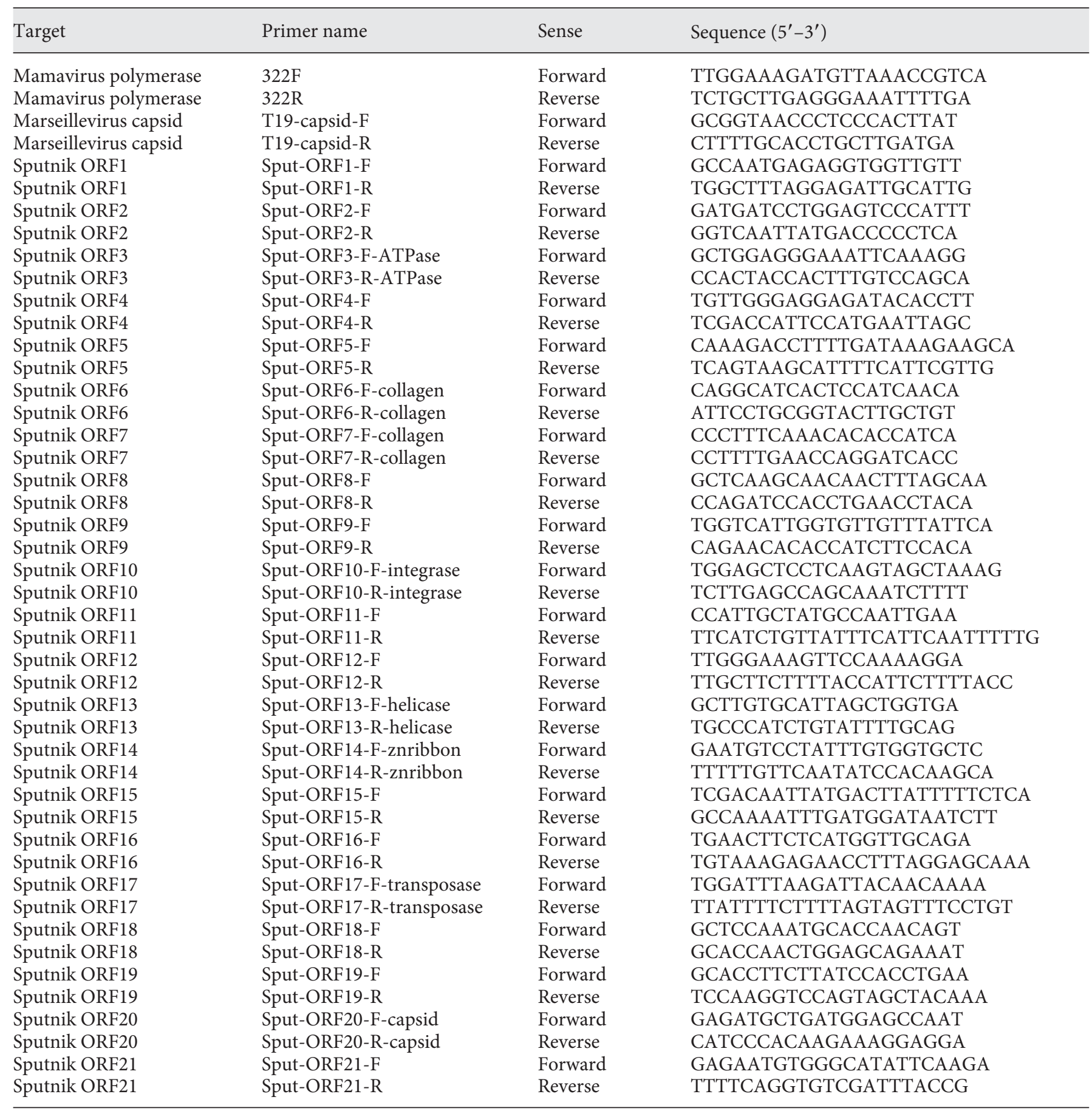

including fibrils, the size of the particle reached $\sim 650 \mathrm{~nm}$ in diameter (fig. 1b). Sputnik also displayed an icosahedral capsid (fig. 1c), which was $\sim 50 \mathrm{~nm}$ in diameter. Sputnik particles were frequently observed at the periphery of or trapped inside Mamavirus fibrils (fig. 1b, d).
Sputnik Particles Enclose Ready-to-Use Viral RNAs

RT-PCR on purified viral particles showed that Sputnik virions enclosed all viral RNAs except one, ORF17 which encodes for a transposase [3] (fig. 2). ORF17 mRNA was not detected inside the sputnik particle but was ex- 
Fig. 1. a Direct observation of Gramstained Mamavirus particles inside A. castellanii. b Transmission electron microscopy image of Mamavirus particles. c, d Transmission electron microscopy image of negatively stained Sputnik particles (c) and Mamavirus surrounded by Sputnik (d).
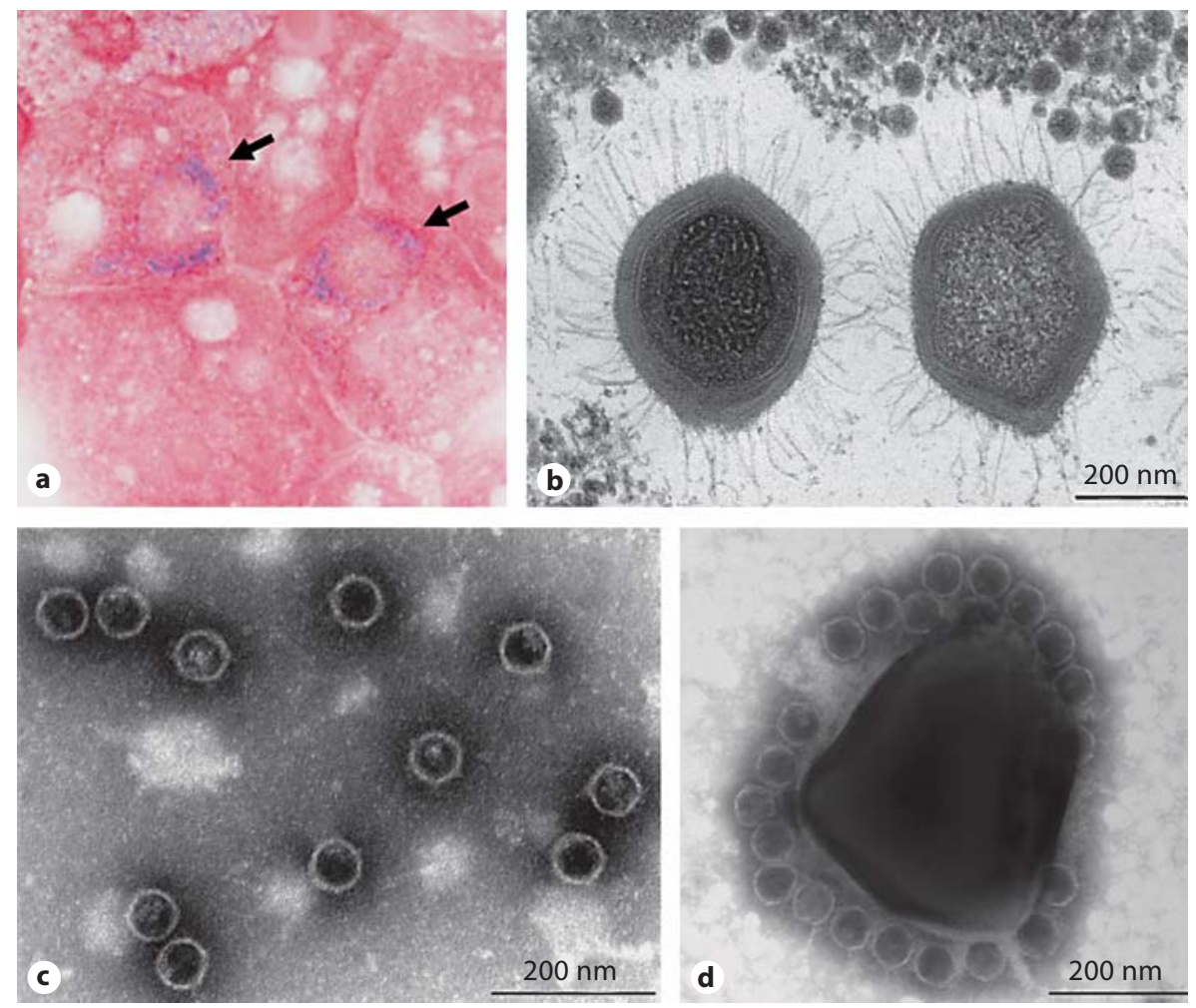

pressed during infection, because all Sputnik mRNAs, including ORF17, were detected at $4 \mathrm{~h}$ p.i. (data not shown). Control for DNA contamination and sequencing of the PCR products confirmed that these RT-PCR products were representative of Sputnik mRNAs.

\section{Ultrastructure of Mamavirus and Sputnik Infection}

Mamavirus and Sputnik co-infections were followed by IFF and electron microscopy at different time points p.i. $\left(\mathrm{T}_{0}, \mathrm{H}_{4}, \mathrm{H}_{8}\right.$ and $\left.\mathrm{H}_{16}\right)$. The results are presented in figure 3.

At $\mathrm{T}_{0}$ (30 min after infection), a large number of Mamavirus particles were seen inside the amoeba cytoplasm as bright and individualized red dots. In contrast, Sputnik particles were observed as a diffuse green signal inside the amoeba cytoplasm with some distinct spots of viral concentration. Electron microscopy showed the presence of numerous Mamavirus-containing vacuoles. Some of them contained several viruses and likely resulted from the fusion of individual vacuoles.

At $4 \mathrm{~h}$ p.i. $\left(\mathrm{H}_{4}\right)$ the Mamavirus viral factories (VFs) were seen as distinct, strongly stained patches in some cells. The appearance of VFs was concomitant with a decrease in the intensity of the cell nuclei. In these cells, no or only a few Mamaviruses were observed, indicating an eclipse phase. In most cases, production of Sputnik virions was initiated at the end of the Mamavirus eclipse phase (around $6 \mathrm{~h}$ p.i.).

At $8 \mathrm{~h}$ p.i., the VFs exhibited a diffuse fluorescent DAPI signal, and Mamavirus production was observed around them. Progeny Sputnik virions were also observed as a bright green fluorescent signal and were localized at one pole of the VF.

At $16 \mathrm{~h}$ p.i., almost all of the cell cytoplasm was filled with newly synthesized Mamavirus and Sputnik viral particles. Some vacuoles containing Sputnik particles could also be discriminated. At later times, amoeba lysis resulted in the release of viral particles in the supernatant (not shown).

\section{Sputnik Hijacks the Mamavirus Factory}

Both IFF (fig. 4a) and electron microscopy (fig. 4b) revealed the presence of Sputnik particles inside the Mamavirus VF. Detection of sputnik particles within the VF suggested that Sputnik assembly and genome encapsidation occurs at this site. In general, Sputnik particles were produced at one side of the VF, but in some cases, the VF harbored two distinct parts: one filled 
Fig. 2. Detection of Sputnik viral transcripts inside the virion.

Fig. 3. a Immunofluorescence of Sputnikand Mamavirus-infected amoeba at 0, 4, 8 and $16 \mathrm{~h}$ p.i. Labeling was obtained with rabbit anti-Mimivirus serum (red) and mouse anti-Sputnik serum (green). Nucleic acids were stained with DAPI (blue). The composite image was created by merging each of the pictures presented above. b Electron microscopy of Sputnik- and Mamavirus-infected amoeba at 0, 4, 8, and $16 \mathrm{~h}$ p.i.
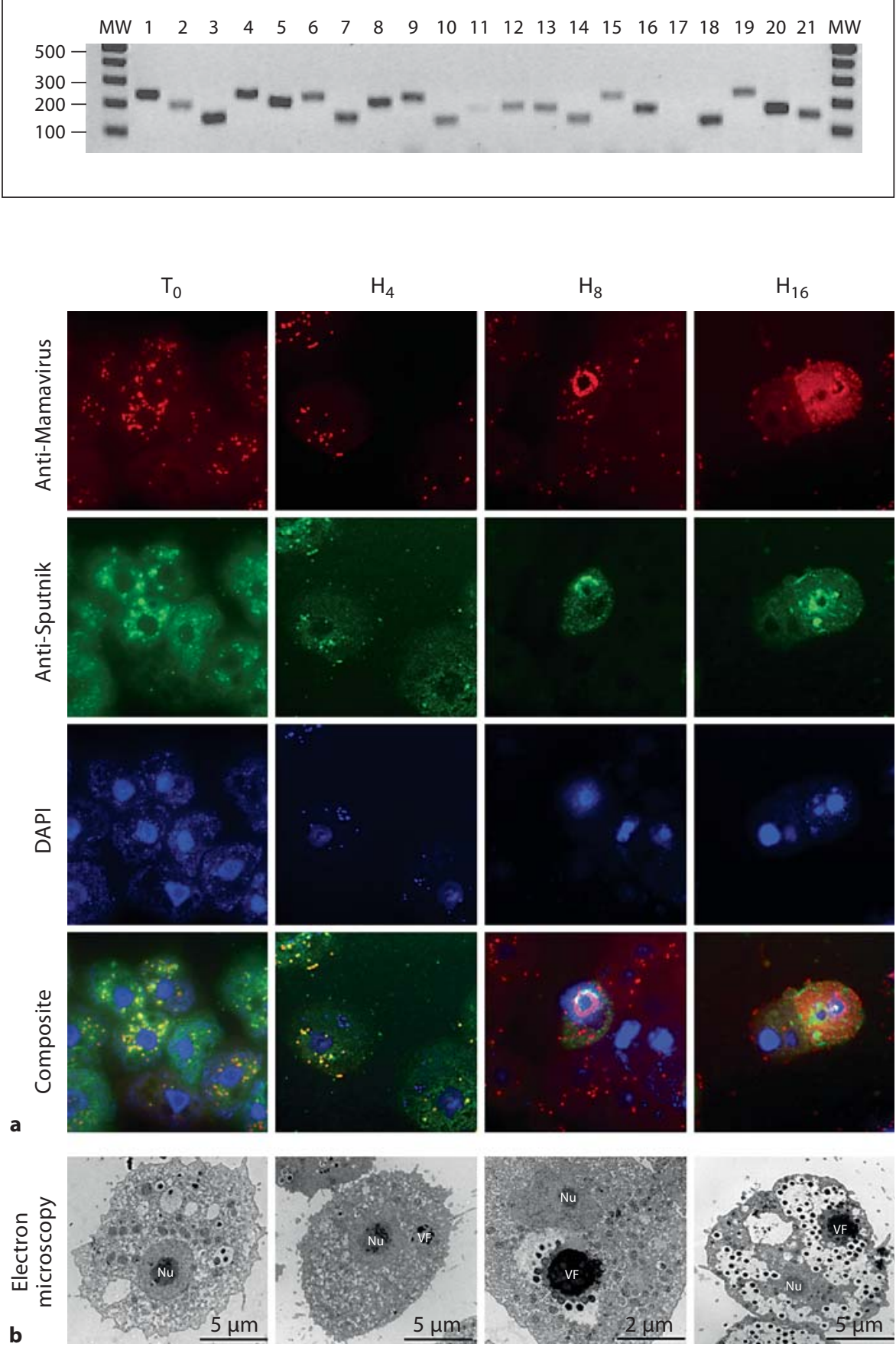

with Sputnik and the other with Mamavirus (fig. 4b). We frequently observed Sputnik production before that of Mamavirus. In the cases of simultaneous production, the spatial separation of the VF may result from competition between Sputnik and Mamavirus for the available space.

The Lifestyle of the Virophage

\section{Co-Infection of A. castellanii with Marseillevirus and} Sputnik

Marseillevirus is a new giant virus isolated from biofilms formed in the waters of an industrial cooling tower [4]. This virus has a particularly fast cell cycle, as the formation of new virions is observed after only $5 \mathrm{~h}$ of infec- 

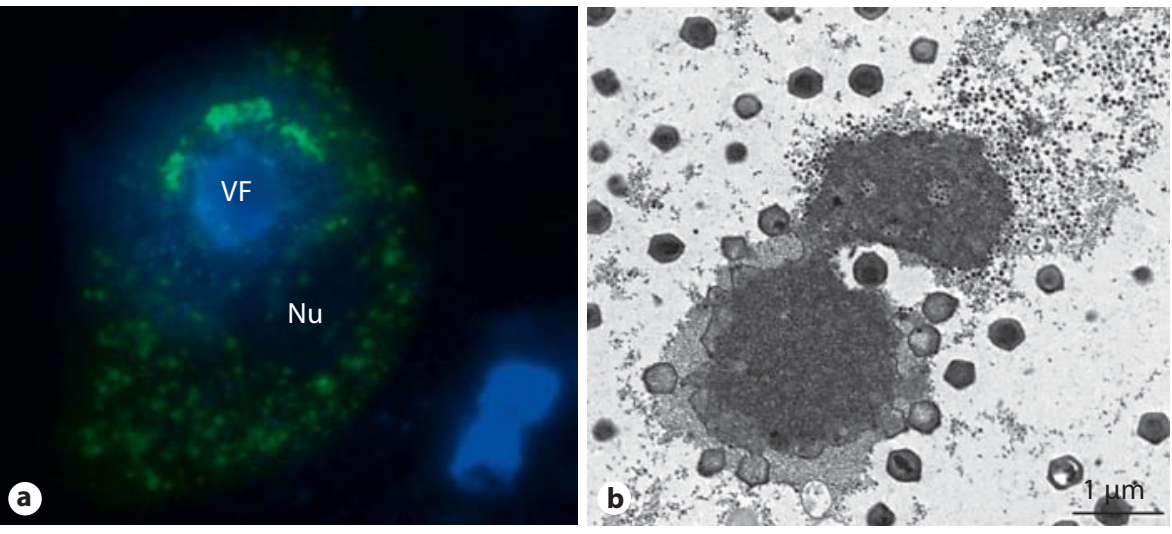

Fig. 4. a Fluorescence microscopy image showing Sputnik particles (labeled with mouse anti-Sputnik serum, green) inside and at the periphery of the VF (stained with DAPI, blue). b Electron micrograph of a VF divided in two parts: one filled with Mamavirus and the other with Sputnik.

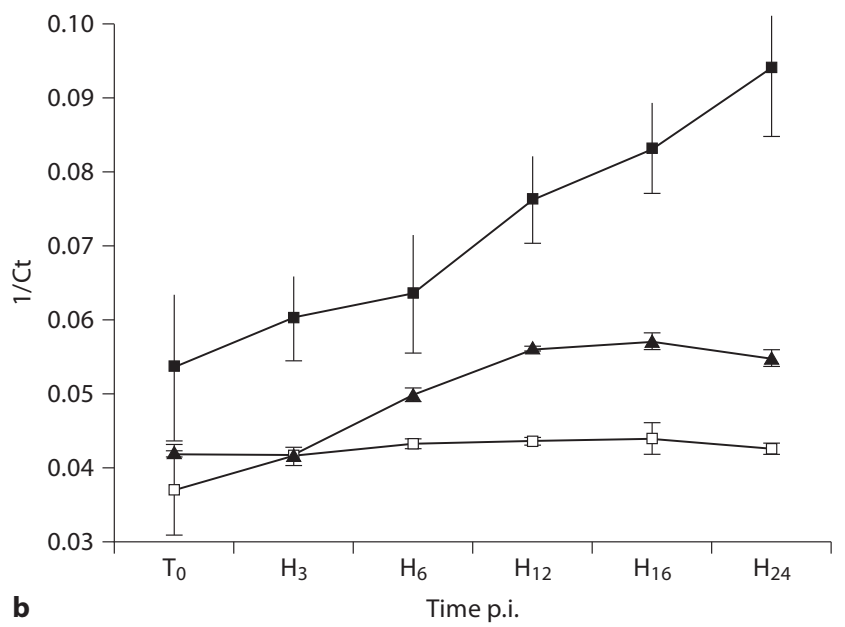

Fig. 5. A castellanii infection. a Infection by Sputnik (filled square) and Marseillevirus (empty square). b Infection by Sputnik (filled square), Mamavirus (triangle), and Marseillevirus (empty square) measured by real-time PCR at different times p.i.

tion in A. castellanii [4]. To assess the effect of Sputnik on the replication cycle of Marseillevirus, $A$. castellanii cells were infected with Sputnik for $24 \mathrm{~h}$ before addition of Marseillevirus particles $\left(\mathrm{T}_{0}\right)$. The infection cycle was then monitored by electron microscopy and by real-time PCR at $\mathrm{H}_{3}, \mathrm{H}_{6}, \mathrm{H}_{12}$, and $\mathrm{H}_{16}$ (table 1 and fig. 5a).

The results showed that, from $\mathrm{T}_{0}$ to $\mathrm{H}_{12}$, Sputnik did not replicate with Marseillevirus and started to be eliminated at $\mathrm{H}_{16}$. Similarly, no Sputnik particles were detected inside the amoeba under electron microscopy. However, the presence of Sputnik had a noticeable effect on the Marseillevirus replication cycle, which was delayed for several hours.

\section{Co-Infection of A. castellanii with Mamavirus,} Marseillevirus, and with or without Sputnik

To evaluate the effect of Marseillevirus on the multiplication cycle of Sputnik and Mamavirus, A. castellanii cells were infected with a mixture of Mamavirus, Sputnik, and Marseillevirus. Infection was followed by realtime PCR targeting specific genes of Mamavirus, Marseillevirus and Sputnik (table 1 and fig. 5b) and by electron microscopy (fig. 6).

At $\mathrm{T}_{0}$ p.i., Mamavirus and Marseillevirus particles were observed inside distinct vacuoles (fig. $6, \mathrm{~T}_{0}$, the Marseillevirus particle is indicated with a black arrow) or inside the same vacuole (fig. $6, \mathrm{~T}_{0}$, black arrow in the inset) 


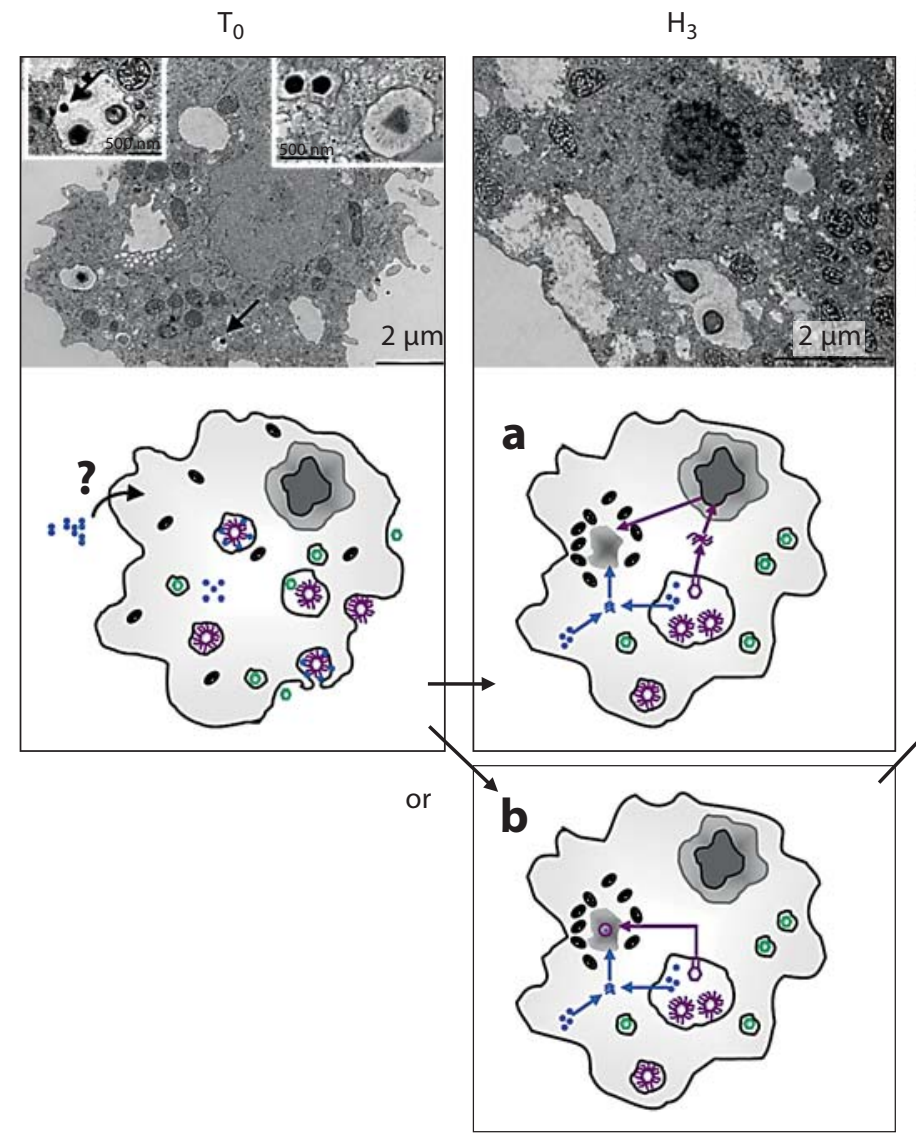

in the amoeba cytoplasm. The presence of both Mamavirus and Marseillevirus in the same vacuole suggests that either they have been internalized at the same time, or that distinct vacuoles have fused together. At $3 \mathrm{~h}$ p.i., it was difficult to detect Mamavirus particles (due to the eclipse phase), but a few Marseillevirus particles were present in the amoeba. The eclipse phase of Mimivirus corresponds to the release of its genetic material into the amoeba cytoplasm. To do this, the Mimivirus particle opens through a unique portal, the stargate, which is located at a single vertex position [5]. This allows the fusion of the viral and host membranes and the formation of a conduit by which the Mimivirus genome is delivered into the host cytoplasm [5] (fig. 6, $\mathrm{H}_{3}$ ). Once in the cytoplasm, Mamavirus genome replication may be similar to that of Asfarviridae, with a transient nuclear replication phase followed by a cytoplasmic replication phase inside the $\operatorname{VF}[6,7]$ (fig. 6a, $\mathrm{H}_{3}$ ). The increase in the AT-content of the nucleus observed between 0 and $3 \mathrm{~h}$ p.i. favors this hypothesis [7]. On the other hand, the Mamavirus replication cycle (genome replication and transcription) might exclusively occur in

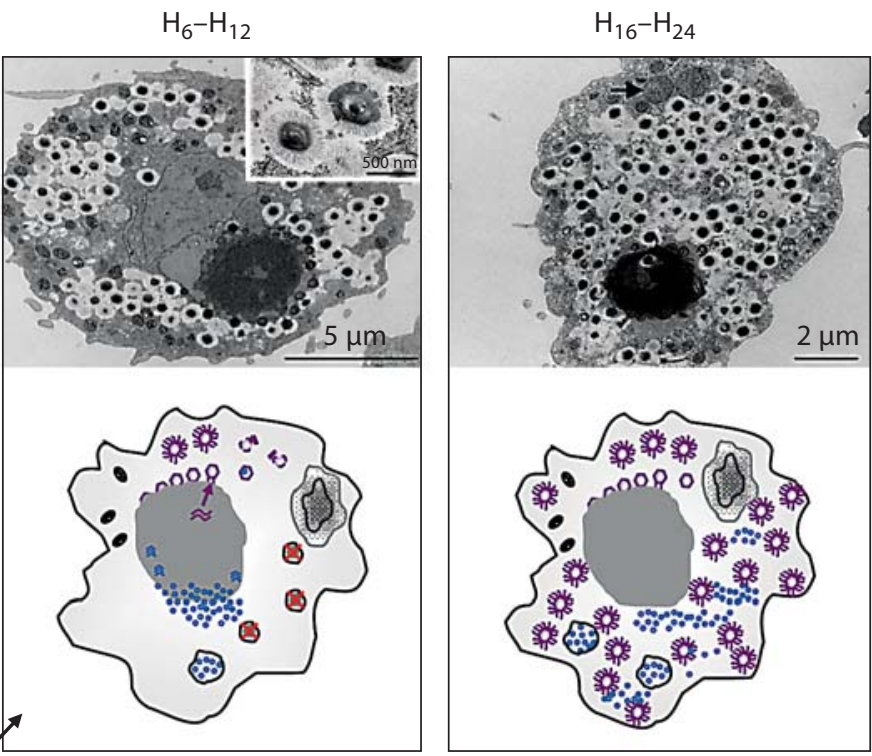

Fig. 6. Electron microscopy and schematic interpretation of Mamavirus, Sputnik, and Marseillevirus replication cycles over a 24-h period.

the cytoplasm, as is the case for Poxviridae (fig. $6 \mathrm{~b}, \mathrm{H}_{3}$ ). Indeed, we observed circular inclusions inside the early Mamavirus factories (fig. 7a), which have previously been hypothesized to represent a ready-to-use core particle holding a functional replication complex [8]. This takeout machinery would be in charge of the transcription of the early Mamavirus genes, initiating the development of the VF [8]. During co-infection with Marseillevirus and Sputnik, multiple Mamavirus seeds were observed, giving a multi-lobular aspect to the early VFs (fig. 7b). This multilobular morphology has previously been observed with Mimivirus [7] and might also indicate the presence of multiple replication centers inside the VF. Finally, after $6 \mathrm{~h}$ p.i., no Marseillevirus could be detected in the cells, and the VFs started to produce Sputnik at one pole. From this time point forward, the course and kinetics of the cycle were similar to that observed in the case of co-infection with Mamavirus and Sputnik only.

IFF and electron microscopy of amoeba infected with Mamavirus alone and Marseillevirus showed at $T_{0}$ p.i., and as described above, that both viruses were able to en- 
Fig. 7. a Electron microscopy showing inclusions with an electron-dense center inside the early VF. b Multilobular viral factory stained with DAPI.
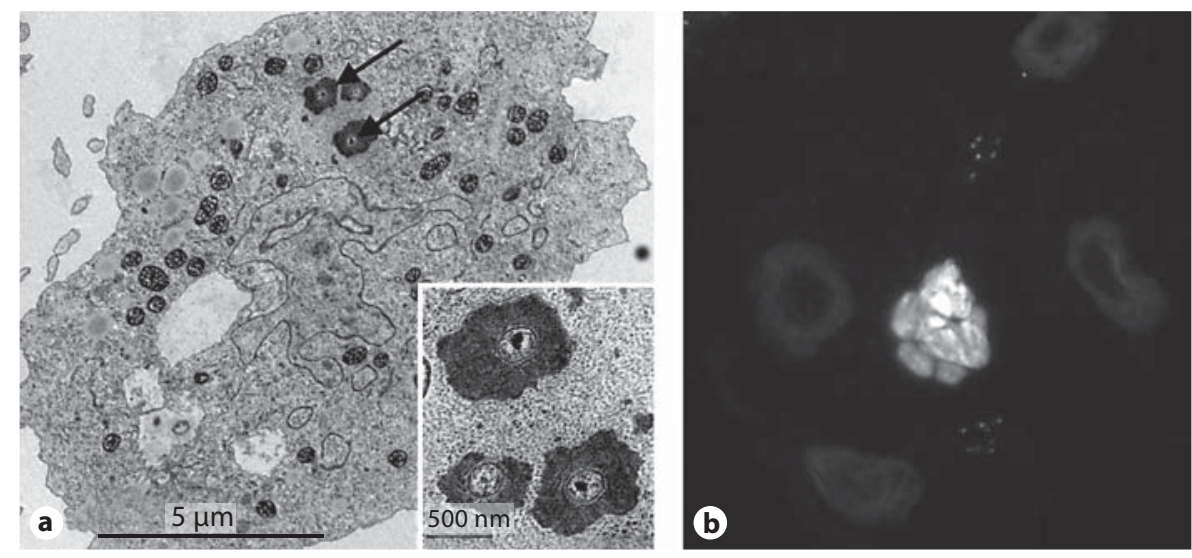

ter the amoeba cells (data not shown). However, at $16 \mathrm{~h}$ p.i. individual cells containing either Marseillevirus or Mamavirus VF were observed. No single cell evidenced the simultaneous presence of both VF, suggesting a competitive exclusion of the viruses. Unlike co-infection in presence of Sputnik and Mamavirus, Marseillevirus replication was not inhibited by the presence of Mamavirus alone (data not shown).

\section{Discussion}

\section{Effect of Sputnik on Another Giant Virus}

In our previous study, we showed that Mamavirus was negatively affected by Sputnik. The adverse effect of Sputnik was also confirmed with Mimivirus, another member of the Mimiviridae family. Thus far, none of the other nucleocytoplasmic large DNA viruses (NCLDV) [9, 10], a group including Poxviruses, Iridoviruses, Phycodnaviruses, and the Asfarvirus, has been associated with a Sputnik-like virus. Here we wanted to go beyond this observation and test the effect of Sputnik on another giant virus. We focused on Marseillevirus, a recently isolated virus that represents a new family of the NCLDV group [4]. Marseillevirus was selected because of its ability to generate VFs in A. castellanii (unlike the other NCLDVs) and its unusually rapid replication cycle $(\sim 5 \mathrm{~h})$. The results showed that Sputnik did not enter the amoeba and did not replicate with Marseillevirus but delayed its replication cycle. The first VFs were detected $6 \mathrm{~h}$ p.i. in $A$. castellanii cells instead of only 3-4 h p.i. with Marseillevirus alone (data not shown). However, once the VFs were produced in the cells, viral replication of Marseillevirus followed the same kinetics whether Sputnik was added or not (data not shown).
When added together, both Mamavirus and Marseillevirus achieved their replication cycle in independent $A$. castellanii cells. In the presence of Sputnik, Marseillevirus was still internalized but did not replicate anymore. The mechanism by which Sputnik interferes with Marseillevirus and/or A. castellanii is unclear, but it might target the early stages of the replication cycle (i.e. adsorption and/or penetration) of the virus through for instance the production of soluble inhibitors.

\section{Mechanism of Sputnik Entry}

Sputnik particles were frequently observed at the periphery of or trapped inside the Mamavirus fibrils (fig. 1b, d). The chemical nature of the fibrils surrounding the outer layer of the Mamavirus particle is not clearly defined. However, it has previously been hypothesized that, according to the large number of ORFs with collagen triple helix repeats in the Mimivirus genome, these fibrils might consist of cross-linked glycosylated collagen [2, 11, 12]. The Sputnik genome also contains two predicted coding sequences containing collagen triple helix motifs (ORF6 and 7). These sequences share homologies with the Mimivirus R196 and R238, respectively. In addition, Sputnik displays mushroom-like fibers at the surface of its capsid [13]. While the function of these fibrils is still uncertain, we can speculate about their role in the adhesion observed between Sputnik and Mamavirus. By interacting with the Mamavirus fibrils, Sputnik would then have an ideal gateway to enter the amoeba. In light of these results, the absence of fibrils in Marseillevirus would, at least in part, explain the inability of Sputnik to replicate with this virus.

\section{Sputnik Virophage}

We first identified Sputnik as a satellite, according to the International Committee on Taxonomy of Viruses, 
Table 2. Traditional satellites (viruses and nucleic acids)

\begin{tabular}{|c|c|c|c|c|c|c|}
\hline & Satellite type & Example $^{1}$ & Genome size & Helper & Host & Ref. \\
\hline ssDNA & Satellite virus & 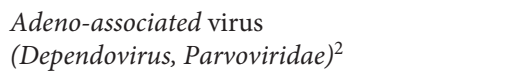 & $4,700 \mathrm{nt}$ & $\begin{array}{l}\text { Adenoviruses or } \\
\text { Herpesviruses }\end{array}$ & Vertebrate & {$[26]$} \\
\hline Positive ssRNA & Satellite virus & $\begin{array}{l}\text { Tobacco necrosis satellite virus } \\
\text { Chronic bee-paralysis satellite virus }\end{array}$ & $\begin{array}{l}1,000 \mathrm{nt} \\
1,239 \mathrm{nt}\end{array}$ & $\begin{array}{l}\text { Chronic bee-paralysis virus } \\
\text { Diverse groups }\end{array}$ & $\begin{array}{l}\text { Animal } \\
\text { Plant }\end{array}$ & $\begin{array}{l}{[27]} \\
{[28]}\end{array}$ \\
\hline dsDNA & Satellite nucleic acids & Enterobacteria phage P4 satellite DNA & $11,627 \mathrm{bp}$ & $\begin{array}{l}\text { Enterobacteria phage } \mathrm{P} 2 \\
\text { (Myoviridae) }\end{array}$ & Bacteria & {$[29]$} \\
\hline ssDNA & Satellite nucleic acids & Tomato leaf curl virus satellite DNA & $682 \mathrm{nt}$ & Geminiviruses (Begomovirus) & Plant & {$[30]$} \\
\hline dsRNA & Satellite nucleic acids & Saccharomyces cerevisiae L-A virus satellite & $500-1,800 \mathrm{bp}$ & Totiviridae & Fungi & {$[31]$} \\
\hline Positive large ssRNA & Satellite nucleic acids & Arabis mosaic virus large satellite RNA & $800-1,500 \mathrm{nt}$ & Arabis mosaic virus & Plant & {$[32]$} \\
\hline Positive small ssRNA & Satellite nucleic acids & Cucumber mosaic virus satellite RNA & $<700 \mathrm{nt}$ & Cucumber mosaic virus & Plant & {$[33]$} \\
\hline Positive circular ssRNA & Satellite nucleic acids & $\begin{array}{l}\text { Velvet tobacco mottle virus satellite RNA } \\
\text { (virusoid) }\end{array}$ & $220-350 \mathrm{nt}$ & Mostly Sobemoviruses & Plant & {$[34]$} \\
\hline Negative ssRNA & Satellite nucleic acids & Hepatitis delta virus (Deltavirus) & $1,700 \mathrm{nt}$ & Hepatitis B virus & $\begin{array}{l}\text { Vertebrate } \\
\text { (human) }\end{array}$ & {$[35]$} \\
\hline
\end{tabular}

Modified from [25].

${ }^{1}$ Satellite viruses encode their own coat protein, while satellite nucleic acids use the coat protein of their helper virus.

${ }^{2}$ Can replicate independently of the helper in some cell cultures.

Table 3. Similarities and differences among satellite viruses, bacteriophages and the Sputnik virophage

\begin{tabular}{llll}
\hline & Satellite viruses & Bacteriophages & Sputnik virophage \\
\hline Nucleic acid & ssDNA or ssRNA & ssDNA, dsDNA, dsRNA, ssRNA & dsDNA (presence of mRNAs) \\
Negative effect on host replication cycle ${ }^{1}$ & Possible & Yes & Yes \\
Independent viral family & Possible & Yes & Yes \\
Genes from host & No & Yes & Yes \\
Genes from other organisms & No & Yes & Yes \\
Independent replication cycle & Possible & No & No
\end{tabular}

${ }^{1}$ Host is the helper virus (satellite viruses), bacteria (bacteriophages) or Mamavirus (Sputnik virophage).

which defines satellites as 'sub-viral agents composed of nucleic acid molecules that depend for their productive multiplication on co-infection of a host cell with a helper virus' [14]. In contrast to satellite nucleic acids (e.g. the enterobacteria phage P4 satellite DNA; table 2), satellite viruses (e.g. the human dependovirus adeno-associated virus, AAV) encode their own coat protein, which would make Sputnik the first dsDNA satellite virus isolated so far (table 2).

However, several lines of evidence show that Sputnik is more than a satellite and represents a new biological entity (table 3). First, from a biological point of view, Sputnik infection results in a 70\% decrease of the Mamavirus cytopathic effect on the amoeba [3]. AAV interference in the replication of its adenovirus helper has previously been observed [15]. However, the formation of some 'diseased' Mamavirus forms in case of co-infection with Sputnik [3] is a phenomenon that has never been described for traditional satellites. In addition, in the absence of a helper virus, AAV particles can penetrate into human cells and viral sequences can integrate into a specific region of the genome [16]. Sputnik alone did not penetrate and replicate inside $A$. castellanii and no integration sites have been identified thus far in the amoeba genome [3]. 
Second, the genetic definition of the satellites states that 'satellite nucleic acids have substantially distinct nucleotide sequences from those of the genomes of either their helper virus or host' [14]. However, Sputnik shares three ORFs with Mamavirus [3]. More surprisingly, Sputnik's genome also contains homologs of genes from viruses infecting archaea and bacteriophages. Sputnik is likely a 'gene robber' that acquired these genes through horizontal gene transfer. In addition, a previous study reported the presence of 16 Mimivirus-like hairpin structures (a polyadenylation signal unique to Mimivirus [17]) in the Sputnik genome, supporting the fact that Sputnik uses the Mamavirus apparatus to carry out its own replication cycle [8].

In our previous study, proteomic analysis of Sputnik particles identified three proteins, i.e. the major capsid protein and two minor virion proteins (proteins encoded by ORF20, ORF08, and ORF19, respectively) [3]. Here we further show that all viral RNAs, except one, were packaged inside the Sputnik virions. This phenomenon has also been observed among Herpesviruses [18, 19], Adenoviruses [20-22] and Mimivirus [2]. As for Adenoviruses [21], the packaging of RNAs into the Sputnik particle was not selective since almost all of the RNAs were detected in the virions. The functions of these ready-to-use RNAs in the virus life cycle are currently unknown but likely reflect the adaptation of Sputnik to its parasitic and competitor behavior toward Mamavirus and other giant viruses.

In this light, Sputnik is then a complete viral entity containing genomic DNA and mRNAs. Sputnik infects Mamavirus and for all of the reasons presented above, a different term is necessary to characterize this new virus. In 1917, Francis d'Herelle described bacteriophages as 'living, filterable, ultramicroscopic microorganisms parasitizing and rapidly multiplying at the expense of actively growing bacteria' $[23,24]$. Genetically, bacteriophages are professional gene pickpockets and are engaged in extensive horizontal gene exchange. Both biological and genetic definitions of bacteriophages, which rely on the notion of parasitism and horizontal gene transfer, are the closest to what we observed with Sputnik. While the original name of Sputnik was kept, the 'virophage' neologism was suggested by analogy to the bacteriophages of d'Herelle. We believe that Sputnik is not the only virophage and that other giant viruses may be parasitized by such virophages. This is confirmed by our recent discovery of a new Mimiviridae member infected by a second strain of virophage (data not shown).

\section{Acknowledgments}

Marie Suzan-Monti, Bernard Campana, and Lina Barassi are acknowledged for their expert assistance. We also thank Benoit Desnues for critical reading of the manuscript. This work was funded by the Centre National de la Recherche Scientifique (crédits récurrents).

\section{Addendum}

During the edition process of this article, a study has shown the entirely cytoplasmic viral replication of Mimivirus (Mutsafi Y, Zauberman N, Sabanay I, Minsky A: Vaccinia-like cytoplasmic replication of the giant Mimivirus. Proc Natl Acad Sci USA 2010;107:5978-5982). According to these results, panel b of figure $6\left(\mathrm{H}_{3}\right.$ p.i.) reflects the accurate replication pathway of Mimivirus.

\section{References}

1 La Scola B, Audic S, Robert C, Jungang L, de Lamballerie X, Drancourt M, Birtles R, Claverie JM, Raoult D: A giant virus in amoebae. Science 2003;299:2033.

2 Raoult D, Audic S, Robert C, Abergel C, Renesto P, Ogata H, La Scola B, Suzan M, Claverie JM: The 1.2-megabase genome sequence of Mimivirus. Science 2004;306: $1344-1350$

3 La Scola B, Desnues C, Pagnier I, Robert C, Barrassi L, Fournous G, Merchat M, SuzanMonti M, Forterre P, Koonin E, Raoult D: The virophage as a unique parasite of the giant Mimivirus. Nature 2008;455:100-104.
4 Boyer B, Yutin N, Pagnier I, Barrassi L, Fournous G, Espinosa L, Robert C, Azza S, Sun S, Rossmann MG, Suzan-Monti M, La Scola B, Koonin EV, Raoult D: Giant Marseillevirus highlights the role of amoebae as a melting pot in emergence of chimaeric microorganisms. Proc Natl Acad Sci USA 2009, in press.

$\checkmark 5$ Zauberman N, Mutsafi Y, Halevy DB, Shimoni E, Klein E, Xiao C, Sun S, Minsky A: Distinct DNA exit and packaging portals in the virus Acanthamoeba polyphaga Mimivirus. PLoS Biol 2008;6:e114.
6 Novoa RR, Calderita G, Arranz R, Fontana J, Granzow H, Risco C: Virus factories: associations of cell organelles for viral replication and morphogenesis. Biology of the Cell/under the Auspices of the European Cell Biology Organization 2005;97:147-172.

7 Suzan-Monti M, La Scola B, Barrassi L, Espinosa L, Raoult D: Ultrastructural characterization of the giant volcano-like virus factory of acanthamoeba polyphaga mimivirus. PLoS ONE 2007;2:e328.

$\checkmark 8$ Claverie JM, Abergel C: Mimivirus and its virophage. Ann Rev Genet 2009;43:49-66. 
$>9$ Iyer LM, Balaji S, Koonin EV, Aravind L: Evolutionary genomics of nucleo-cytoplasmic large DNA viruses. Virus Res 2006;117: 156-184.

-10 Iyer LM, Aravind L, Koonin EV: Common origin of four diverse families of large eukaryotic DNA viruses. J Virol 2001;75: $11720-11734$

-11 Xiao C, Chipman PR, Battisti AJ, Bowman VD, Renesto P, Raoult D, Rossmann MG: Cryo-electron microscopy of the giant Mimivirus. J Mol Biol 2005;353:493-496.

$>12$ Claverie JM, Abergel C, Ogata H: Mimivirus. Curr Top Microbiol Immunol 2009;328:89121.

-13 Sun S, La Scola B, Bowman VD, Ryan CM, Whitelegge JP, Raoult D, Rossmann MG: Structural studies of the Sputnik virophage. J Virol 2010;84:894-897.

14 Fauquet CM, Mayo MA, Maniloff J, Desselberger U, Ball LA: Virus Taxonomy. Eighth Report of the International Committee on Taxonomy of Viruses. London, Elsevier Academic Press, 2005.

15 Parks WP, Casazza AM, Alcott J, Melnick JL: Adeno-associated satellite virus interference with the replication of its helper adenovirus. J Exp Med 1968;127:91-108.

16 Kotin RM, Siniscalco M, Samulski RJ, Zhu XD, Hunter L, Laughlin CA, McLaughlin S, Muzyczka N, Rocchi M, Berns KI: Site-specific integration by adeno-associated virus. Proc Natl Acad Sci USA 1990;87:2211-2215.
7 Byrne D, Grzela R, Lartigue A, Audic Sp, Chenivesse S, Encinas Sp, Claverie JM, Abergel C: The polyadenylation site of Mimivirus transcripts obeys a stringent 'Hairpin rule'. Genome Res 2009;19:1233-1242.

18 Bresnahan WA, Shenk T: A subset of viral transcripts packaged within human cytomegalovirus particles. Science 2000;288: 2373-2376.

19 Sciortino M-T, Suzuki M, Taddeo B, Roizman B: RNAs extracted from herpes simplex virus 1 virions: apparent selectivity of viral but not cellular RNAs packaged in virions. J Virol 2001;75:8105-8116.

20 Xing L, Tikoo SK: Viral RNAs detected in virions of porcine adenovirus type 3 . Virology 2004;321:372-382.

21 Xing L, Tikoo S: Packaging of viral RNAs in virions of adenoviruses. Virol J 2009;6:16.

22 Chung SW, Arnott JA, Yang Y, Wong PMC: Presence of prepackaged $\mathrm{mRNA}$ in virions of DNA adenovirus. Journal of Biological Chemistry 2003;278:50635-50640.

23 Bronfenbrenner JJ, Korb C: Studies on the bacteriophage of d'Herelle: I. Is the lytic principale volatile? J Exp Med 1925;41:7379.

24 d'Herelle F: Sur un microbe invisible antagoniste des bacilles dysentriques. Compt Rend Acad Sci 1917;clxv:373.

25 Dimmock N, Easton A, Leppard K: Introduction to Modern Virology, ed 6. Hoboken, John Wiley and Sons, 2009.

26 Berns KI, Giraud C: Biology of adeno-associated virus. Curr Top Microbiol Immunol 1996;218:1-23.
27 Dodds JA: Satellite tobacco mosaic virus. Curr Top Microbiol Immunol 1999;239: 145-157.

28 Olivier V, Blanchard P, Chaouch S, Lallemand P, Schurr F, Celle O, Dubois E, Tordo $\mathrm{N}$, Thiéry R, Houlgatte R, Ribière M: Molecular characterisation and phylogenetic analysis of chronic bee paralysis virus, a honey bee virus. Virus Res 2008;132:59-68.

29 Christie GE, Calendar R: Interactions between satellite bacteriophage $\mathrm{p} 4$ and its helpers. Ann Rev Genet 1990;24:465-490.

30 Briddon RW, Stanley J: Subviral agents associated with plant single-stranded DNA viruses. Virology 2006;344:198-210.

31 Wickner RB: Double-stranded RNA viruses of Saccharomyces cerevisiae. Microbiol Rev 1996;60:250-265.

32 Mayo MA, Taliansky ME, Fritsch C: Large satellite RNA: molecular parasitism or molecular symbiosis. Curr Top Microbiol Immunol 1999;239:65-79.

33 Garcia-Arenal F, Palukaitis P: Structure and functional relationships of satellite RNAs of cucumber mosaic virus. Curr Top Microbiol Immunol 1999;239:37-63.

-34 Symons RH, Randles JW: Encapsidated circular viroid-like satellite RNAs (virusoids) of plants. Curr Top Microbiol Immunol 1999;239:81-105.

35 Taylor JM: Human hepatitis delta virus: an agent with similarities to certain satellite RNAs of plants. Curr Top Microbiol Immunol 1999;239:107-122. 